УДК 94(100)"1939/1945":355.483(498.31:498.71)"1944"

СВСЕСВ I.Г.

https://orcid.org/0000-0003-1450-1378

ГРИЦЮК В.М.

https://orcid.org/0000-0001-9877-1900

кИДОНь В.І.

https://orcid.org/0000-0002-3606-8061

КРИВИЗЮК Л.П.

https://orcid.org/0000-0001-9094-4061

https://doi.org/10.33577/2313-5603.36.2021.182-206

\title{
ОПЕРАЦІЇ РСЧА ТА ВЕРМАХТУ НА ЯССЬКО-КИШИНІВСЬКОМУ НАПРЯМКУ (5.04 - 6.06.1944р.): ЗАБУТІ СТОРІНКИ ДРУГОЇ СВІТОВОЇ ВІЙНИ
}

У статті автори на основі наукових публікацій та архівних матеріалів органів 3 вивчення та використання досвіду війни досліджують маловідомі операції, які здійснювались протиборчими сторонами на яссько-кишинівському напрямку у квітні-червні 1944 року.

Перша Яссько-Кишинівська операція відноситься до числа військових операцій, що велися на Східному фронті та повністю ігнорувалися радянськими істориками та експертами. Про це писав відомий військовий історик Девід Гланц. Протягом 76 років після завершення Другої світової війни, радянські та російські історики і теоретики старанно витирали з історичних свідоцтв будьякі спогади та згадування про роль 2-го та 3-го Українських фронтів у першій битві за Ясси і Кишинів, коли радянські війська двох фронтів намагалися просунутися на територію Румунії у квітні-травні 1944 року. Як і в багатьох інших військових операціях Червоної Армії, які розглядаються авторами статті, провалених під час проведення операції, вони зробили це навмисно, викресливши цей наступ та відправивши його до довгого листа «забутих битв» німецькорадянської війни.

Ключові слова: Друга світова війна, 2-й Український фронт, радянські війська, німецькі війська, яссько-кишинівський напрямок.

Євсєєв Ігор Григорович, науковий співробітник науково-дослідного центру воєнної історії Національного університету оборони України імені Івана Черняховського, м. Київ.

Грицюк Валерій Миколайович, кандидат історичних наук, доцент, провідний науковий співробітник науково-дослідного центру воєнної історії Національного університету оборони України імені Івана Черняховського, м. Київ.

Кидонь Володимир Іванович, кандидат історичних наук, провідний науковий співробітник науково-дослідного центру воєнної історії Національного університету оборони України імені Івана Черняховського, м. Київ.

Кривизюк Леонід Петрович, кандидат історичних наук, доцент, заступник завідувача кафедри військової підготовки Національної академії сухопутних військ імені гетьмана Петра Сагайдачного, м. Львів.

(С) Євсєєв І.Г., Грицюк В.М., Кидонь В.І., Кривизюк Л.П., 2021 
Постановка проблеми. В науковій літературі, присвяченій воєнно-історичному аналізу подій Другої світової війни традиційно висвітлюються факти, які реально відбулися у минулому. Щоправда, оцінка історичних фактів може бути різною, ті самі події можуть подаватись у негативі чи позитиві, звеличуватись чи применшуватись, отримувати відтінки героїзму, жертовності або безглуздя та бездарності. Особливе розмаїття поглядів науковців спостерігається в останні роки. Проте дуже мало робіт, у яких здійснюється оцінка не реалізованих замислів воюючих сторін (Грицююк, 2012: 121).

Водночас всебічне об'єктивне та незаангажоване вивчення воєнно-історичних подій в Україні періоду Другої світової війни важливе з погляду встановлення історичної правди. На сьогодні завдяки розсекреченим архівним документам, що містять матеріали узагальненого бойового досвіду (журнали бойових дій, звіти про бойову діяльність, зведення узагальненого бойового досвіду тощо), ми маємо можливість об'єктивно оцінити діяльність військово-політичного (військового) керівництва та хід проведення маловідомих операцій, що проводились протидіючими сторонами у роки Другої світової війни. Зокрема, це стосується розвитку воєнних дій між Робітничо-Селянською Червоною Армією (РСЧА) і Вермахтом, що відбувались на яссько-кишинівському напрямку у квітні-червні 1944 р.

У радянській та російській історичній літературі бойові дії в Румунії навесні та початку літа 1944 р. інколи називались «боями місцевого значення», хоча насправді вони за своїм політичним i воєнним змістом такими не були. Їх інтенсивність була високою, про що свідчать значні втрати в особовому складі та техніці 3 боку усіх протиборчих сторін (Назария, Поливцев, 2015: 228; Великая Отечественная война Советского Союза 1941-1945: Краткая история, 1984: 346; Бодрихин, 2010: 88).

Аналіз попередніх досліджень $i$ публікацій. Проведений авторами аналіз історіографічних джерел провідних зарубіжних (Курт фон Типпельскирх 1998; Glantz, 2007), радянських (Мини, 1947; Ясско-Кишиневские Канны, 1964; Тельпуховский, 1959; Освобождение Юго-Восточной и Центральной Европь войсками 2-го и 3-го Украинских фронтов, 1970), російських (Бодрихин, 2010; Малютина, 2018; Малютина, 2019; Золотарев, 2010; Никитенко, 1994), сучасних українських дослідників (Грищюк, 
2012), спогадів безпосередніх учасників подій (Генераль $u$ офицеры вермахта рассказывают..., 2009; Клевцов, 1989; Рудель, 2003; Малиновский, 1959), а також низки фундаментальних праць з історії Другої світової війни (Великая Отечественная война Советского Союза 1941-1945: Краткая история, 1984; Великая Отечественная война. 1941-1945. Военно-исторические очерки, 1999; Стратегічні та фронтові операиії на території Украйни у 1943-1944 роках, 2015; Важнейшие операџии Великой Отечественной войны 1941-1945 г2., 1956; Великая Отечественная война 1941-1945 годов, 2015; История Второй мировой войны 1939-1945 г2., 1977; История Великой Отечественной войны Советского Союза 1941-1945 г2., 1944) свідчить про те, що зазначена наукова проблематика є маловивченою і в більшості із вказаних джерел розглядається фрагментарно. Разом 3 тим найбільш детально розглянуті маловідомі історичні факти про не завершені наступальні операції РСЧА у квітні-травні 1944 року на яссько-кишинівському напрямку у фундаментальній науковій праці, що складається 3 воєнно-історичних нарисів про події Другої світової війни (Великая Отечественная война. 1941-1945. Военно-исторические очерки, 1999). Але зазначена праця не містить грунтовного дослідження бойових операцій на ясському плацдармі, які були проведені німецьким командуванням наприкінці травня і початку червня 1944 року.

Метою даної статті є спроба розглянути маловідомі події Другої світової війни, пов'язані 3 перерозподілом основних зусиль 2-го Українського фронту (УФ) на заключному етапі Уманської наступальної операції (5-25 березня 1944 р.) та проведенням невдалих наступальних операцій РСЧА і Вермахту на яссько - кишинівському напрямку у квітні-червні 1944 року.

Вивчивши великий масив архівних матеріалів, автори наполягають саме на такій назві цієї наступальної операції, за якою пізніше закріпилась назва «Умансько-Ботошанська» (5 березня17 квітня 1944 р.). По-перше, Уманська наступальна операція була спланована командуванням 2 УФ на виконання директиви Ставки Верховного Головнокомандування (ВГК) (ЦАМО, 240 2779 - 1140: 1 - 7). По-друге, матеріали позачергового донесення командувача 2 УФ Верховному Головнокомандувачу від 26 березня та Опису Уманської операції, підготовленого відділом 
3 використання досвіду війни оперативного управління штабу фронту, свідчать що датою закінчення Уманської наступальної операції є 25 березня 1944 року, коли «...війська 2 УФ у важких умовах повного бездоріжжя за 21 день на головному напрямку 3 боями пройшли майже 320 км. За час операції розгромили частини 8-ї армії (А), 1-ї танкової армії (ТА) та 4-ї румунської армії...» та основними силами вийшли до Державного кордону на р. Прут. Вже у ході подальшого розвитку наступу 6 квітня 1944 року війська фронту захопили місто Ботошани (ЦАМО, 240 2779 - 1274: 1, 38; ЦАМО, 240 - 2779 - 1146: 120 - 122).

Крім цього, прийняті в радянській історіографії хронологічні рамки закінчення Дніпровсько-Карпатської стратегічної наступальної операції (17 квітня 1944 року), на думку авторів, є неточними. На разі виключається розгляд операцій (бойових дій) 2 УФ на яссько-кишинівському напрямку та 3 УФ 3 плацдармів на Дністрі, які тривали до 6 травня включно, коли рішенням Ставки ВГК ці фронти перейшли до оборони (ЦАМО, 148 - 3763 - 166: 359; Великая Отечественная война. 19411945. Военно-исторические очерки, 1999: 34).

Виклад основного матеріалу. Внаслідок наступу військ 2 УФ в період 35 до 20 березня уманське угруповання Вермахту зазнало великих втрат. Група армій «Південь» виявилася розчленованою на дві частини. 1 ТА була відкинута на північний захід, 8 А - на південь. Отже, для військ 2 УФ склалися сприятливі умови для організації подальших ударів у західному та південно-західному напрямках. Це відкривало для радянського командування нові можливості з розгрому противника (Cтратегічні та фронтові операції на території України у 19431944 роках, 2015: 265).

Використовуючи вигідну ситуацію Ставка ВГК 22 березня уточнила завдання фронтам, зокрема, щодо зміни напрямку наступу 2 УФ. Вважаючи, що замкнути оточення і знищити 1 ТА противника зможуть війська 1 УФ самостійно, Ставка ВГК вирішила повернути головні сили 2 УФ на південь для наступу по правому і лівому берегах Дністра, аби виходом до узбережжя Чорного моря оточити 8-му, 6-ту німецькі та 3-тю румунську армії й у взаємодії з 3 УФ знищити їх. 
2 УФ отримав завдання: на правому крилі фронту ударом однієї-двох загальновійськових і двох танкових армій уздовж західного берега Дністра на південь опанувати рубежем Унгени, Кишинів і вийти на р. Прут; на лівому крилі фронту, включаючи і 5 гв. ТА, завдати удару з рубежу Кодима, Первомайськ також на південь і опанувати рубежем Бендери, Тирасполь, Роздільна, відкидаючи противника до Чорного моря і не допускаючи відходу його за р. Дністер (ЦАМО, $148 a-3763$ - 166: 67, 68).

Поворот головних сил 2 УФ на південь для виконання поставлених Ставкою завдань здійснювався в ході наступу за дуже складних умов, при розтягнутому фронті. Війська 40 А, наступаючи уздовж південного берега Дністра, 29 березня впритул підійшли до Хотина, де з'єдналися з частинами 1 ТА 1 УФ і тим самим відрізали 1 ТА противника шлях до відходу на південь. Війська 4 гв. А, 27 А, 52 А, і 53 А, 5 гв. ТА, 2 ТА і 6 ТА успішно наступали вздовж обох берегів Дністра в напрямах на Ясси й уздовж залізниці в бік Одеси. 26 березня війська 2 УФ вийшли до кордону з Румунією по Пруту і розпочали форсування ріки (Стратегічні та фронтові операџії на території Украӥни у 19431944 роках, 2015: 267, 269; Важнейшие операџии Великой Отечественной войны 1941-1945 г2.: Сборник статей, 1956: 304). В ніч на 28 березня з'єднання правового крила фронту форсували Прут та просунулися на 20-40 км у глибину румунської території. Однак, на підступах до Ясс та Кишинева вони зустріли запеклий опір противника (Великая Отечественная война 19411945 годов: Т. 1, 2015: 464).

Наступ військ 2 УФ в напрямках Ясс і Кишинева створював загрозу оточення групи армій «А» в межиріччі Південного Бугу і Дністра. Зважаючи на це, німецьке командування почало відвід 3 Південного Бугу своїх 8 А, та 6 A, а також 3-ї румунської армій на позицію за нижню течію Дністра (Кишинів, Ясси), що дозволило військам 3 УФ наростити темпи наступу на Одесу. Ділянка фронту, на яку було відведено німецькі та румунські частини, свої лівим флангом примикала до Карпат, що надавало можливість 3 достатніми резервами прикривати їм район Балкан (Генераль и офицеры вермахта рассказывают..., 2009: 72). 
Одночасно німецьке командування, намагаючись зупинити просування військ 2 УФ, безперервно підсилювало свої війська на яссько-кишинівському напрямку. Для закриття величезного пролому, що утворився в результаті поразки лівого крила 1 ТА і правового крила 8 А Вермахту, воно висунуло на ясський напрямок 4-ту румунську армію (вісім дивізій і одна бригада), а на кишинівський (для підсилення 8 А) - сім румунських дивізій та дві бригади. три дивізії, в тому числі дві румунські прибули до 8 А зі складу групи армій «А», що оборонялась між Дністром та Прутом. Ці з'єднання мали посилити все ще слабку оборону та призупинити наступ радянських військ у межіріччі та в районі Ясс. Разом проти 2 УФ до кінця квітня було перекинуто 3 Румунії і групи армій «А» одне армійське та 8 корпусних управлінь, вісімнадцять дивізій і три бригади. Це потужне угруповання зайняло важливі горні перевали в Карпатах i оборонний рубіж по лінії Пашкани - Унгени - Оргіїв і по p. Реут, прикриваючи дорогу до важливих для німців нафтових районів поблизу міста Плоєшти (История Второй мировой войны 1939-1945 г2., 1977: 90; История Великой Отечественной войны Советского Союза 1941-1945 г2., 1962: 202; Курт фон Типпельскирх, 1998: 484; Мини, 1947: 53; Великая Отечественная война Советского Союза 1941-1945: Краткая история, 1984: 294).

Війська правового крила 2-го Українського фронту 5 квітня продовжили наступ на правому березі р. Прут і передовими частинами заволоділи містом і крупним вузлом доріг Дорохой та наблизились до Тиргу-Фрумоса i Ботошан. Противник, посиливши своє угруповання в районах Корнешти (24-ю танковою дивізією (mд), моторизованою дивізією (мд) СС «Велика Німеччина», 79 піхотну дивізію (nd), 376 nd) і Північні Дубоссари (46 nd, 62 nd, 123 nd, що раніше протидіяли з 3 УФ) постійними контратаками не допускав прориву радянських військ в південному напрямку та виходу на тили і комунікації 8-ї та 6-ї німецьких армій (ЦАМО, 240 - 2779 - 1150: 18, 19).

Цього ж дня на вимогу Ставки ВГК щодо прискорення висунення правого крила фронту на рубіж річок Серет і Бахлуй та оволодіння районом Дорохой, Ботошани, Ясси, командувач 2 УФ доповів, що на правовому крилі фронту противник будує 
оборону на р.Серет та підсилює Кишинівський напрямок. Зокрема, на цей напрямок були перекинуті його $62 n d, 46 n d$, $79 n d$ і $370 n d, 23 m \partial$ та $24 m \partial$. Враховуючи зазначене, командувач фронту запропонував здійснити наступ правим крилом фронту у складі 27 A, 40 А, підсилених 3 гв. танковим корпусом $(m \kappa)$ та в подальшому 7 гв. А, при цьому головного удару завдати у напрямку Балатина, Тиргу-Фрумос, Роман, Бакеу. На напрямку головного удару використати 27 А. В подальшому планувалось вивести на цей напрям 7 гв. А та 5 гв. ТА у складі двох танкових корпусів. Операцію розпочати 8 квітня з наступом 40 А та 27 А. Найближче завдання - вихід на р. Серет. Завдання лівого крила фронту (4 гв. А, 53 А і 5 гв. ТА, 2 ТА і 6 ТА) полягала у продовженні наступу з метою оволодіння районом Кишинева $\mathrm{i}$ виходу на р. Прут. Ставкою ВГК було погоджено рішення командувача фронту, але запропоновано посилити наступ $27 \mathrm{~A}$ 2-ю або 6-ю танковою армією (ЦАМО, $148 a-3763$ - 166: 78 80; ЦАМО, 240 - 2779 - 1150: 20, 21).

Для виконання поставленого завдання 2 УФ мав достатньо сил. До його складу входили сім загальновійськових, три танкові і одна повітряна армія (ПА), окремі кавалерійський, два механізованих (мк) і два $m \kappa$. Загалом нараховувалось 56 стрілецьких (cd) і 3 кавалерійські дивізії (кд), шість $т к$ і чотири мк. Бойовий та чисельний склад фронту нараховував 377, 5 тис. осіб особового складу в бойових частинах, 8, 3 тис. гармат та мінометів, 326 танків, 515 бойових літаків. Йому протистояла армійська група «Велер» (8-ма німецька та 4-та румунська армії) і частка з’єднань (три дивізії) 6 А Вермахту, що входили до групи армій «Південна України». Це угруповання нараховувало двадцять чотири дивізії (з них п'ять тд та три мд, 160 тис. осіб особового складу, до 3 тис. гармат та мінометів, більше 160 танків та майже 600 бойових літаків (Великая Отечественная война. 1941-1945. Военно-исторические очерки. 1999: 47).

У цій обстановці оперативний план дій Південної групи армій німецьких військ полягав у тому, щоб за рахунок перегрупування частки своїх сил на північ та висування нових сил 3 глибини не допустити прориву радянських військ у тил 6 А. Були визначені наступні завдання: 8 А утримувати рубіж між 
Балтою і Первомайськом з метою запобігання загрози флангу 6 А, що відступала, а потім остаточно зайняти позицію між річками Прут і Дністер на лінії Оргіїв, Скуляни; 4-й румунській армії, що висувалася з глибини, утримувати лінію р. Прут між Чернівцями та Яссами та, у разі здійснення радянськими військами переправи через р. Прут, зайняти оборону проходів через Карпати до Тиргу-Няму (ЦАМО, 240 - 2779 - 992: 1, 2).

Відповідно до затверджено плану операції командування ЧА 8 квітня 27 А і 40 А за підтримки 2 ТА зробили спробу потужним ударом прорвати німецьку оборону противника поблизу ТиргуФрумос. Одночасно, війська 52 А і 6 ТА завдали допоміжного удару північніше Ясс, намагаючись розгромити оборонний фронт румунських військ і вийти на оперативний простір (Glantz, 2007: 52).

Зранку 9 квітня війська радянського ударного угруповання перейшли в наступ. В авангарді 27 А діяли дві $c \partial 35 c \kappa$, що завдавав удару в південному напрямку 3 району Хирлеу на Тиргу-Фрумос. Радянські війська розгромили румунські підрозділи, що обороняли Тиргу-Фрумос, захопили навколишні населені пункти та продовжили наступ вперед. Незабаром підрозділи 42 гв. сд 40 А опанували Пашкань, який обороняла румунська 6 nd.

Тим часом передові загони 2 ТА просувалися східніше від Тиргу-Фрумос, підтримуючи війська 27 А, при цьому основні сили цієї армії внаслідок бездоріжжя і складних переправ через p. Прут затрималися на марші та із запізненням вступили в бій на 4 дні пізніше, лише 12 квітня. У взаємодії зі з'єднаннями 27 А 2 ТА відбивала контрудар танкового угруповання противника в районі Поду-Ілоаей. 3 тих самих причин 5 гв. ТА розтягнулася та почала бойові дії тільки 15 квітня. Враховуючи ситуацію, що склалася, німецьке командування 8 А ввело в бій 23 mд та 24 mд, а також свій резерв - панцер-гренадерську моторизовану дивізію «Велика Німеччина». Водночас для утримання району ТиргуФрумоса командувач 2 УФ перенацілив до району бойових дій ще дві дивізії 35-го корпусу, які вступили в бій з німецькою елітною частиною. Однак, німецькі війська, скориставшись системою підготовлених рубежів, перейшли в контрнаступ та 11 квітня відкинули війська 27 А від цього важливого 
населеного пункту (Великая Отечественная война. 1941-1945. Военно-исторические очерки, 1999: 47; ЦАМО, 240 - 2779 1150: 42; Glantz, 2007: 63).

У напівоточенні в Тиргу-Фрумос опинилися розрізнені угруповання радянських військ: 206 сd, 3-ї гвардійської повітрянодесантної (ndd) та 93 гв. сд, які з боями виходили 3 оточення невеликими осередками. Частини мд «Велика Німеччина» зміцнили свої оборонні позиції навколо Тиргу-Фрумос, що утворювали широку дугу північніше міста. На правому фланзі оборони навколо міста свої позиції утримували підрозділи німецької 24 mд, що оборонялися на рубежі Поду-Ілоаей-Лецкань, що західніше Ясc (Glantz, 2007: 69). У цей час на лівому крилі війська фронту опанували Дубоссари, Грігоріопіль, вийшли на p. Дністер та продовжили бої за розширення плацдарму (Великая Отечественная война. 1941-1945. Военно-исторические очерки. 1999: 47).

Внаслідок стрімкого наступу війська 2 УФ відірвались на відстань 300 км від залізничних станцій постачання запасів, тому боєприпаси, пальне, продукти харчування підвозились із значним запізненням. Крім цього, весняним паводком були зірвані мости на рр. Південний Буг, Дністер, Прут, Жижія, Сирет, Сучава. В таких умовах затримувалось перегрупування об'єднань 3 лівого крила фронту на напрямок головного удару (Великая Отечественная война. 1941-1945. Военно-исторические очерки. 1999: 47). На цей момент між радянськими і німецькими військами склалося співвідношення сил по піхоті 3:1, танках 1:6, артилерії 2:1, за яким подальший наступ військ 2 УФ був недоцільним. Тому, командувач фронту 12 квітня прийняв рішення про перегрупування своїх військ та завдання головного удару західніше від Ясс (ЦАМО, 240 - 2779 - 992: 4).

К середині квітня війська 2 УФ займали рубіж Радівці Пашкани - Оргіїв - Дубосари (История Великой Отечественной войны Советского Союза 1941-1945 г2., 1962: 82). На цей час погодні умови дозволили радянським військам здійснити перегрупування на яссько-кишинівському напрямку. Зокрема, для продовження наступу в район на північ від Тиргу-Фрумос, у смугу між 40 А та 27 А $з$ лівого крила 2 УФ була перекинута 
7 гв. А. 18 квітня командувач 2 УФ подав до ставки ВГК уточнене рішення на проведення наступу: прорвати оборону противника на захід від Ясс, на ділянці Пашкани, Тиргу-Фрумос шириною 15 км і завдати головного удару по лівому берегу p. Серет на Бечешті, в подальшому розвивати наступ на Бакеу або Васлуй. Почати операцію планувалось 27-29 квітня. Одночасно планувалось завдати допоміжних ударів на ясському та кишинівському напрямках. Тобто, здійснивши перегрупування військ, подальшим планом командувача фронту передбачалось ударом 53 гв. А і 5 гв. А на Кишинів зі сходу, 52 А і 27 А у взаємодії 3 2 ТА на Ясси 3 півночі, 7 гв. А у взаємодії з 5 гв. ТА і частиною сил 40 А (чотирма $c \partial$ ) 3 півночі на Тиргу-Фрумос прорвати оборону противника та заволодіти містами Ясси та Кишинів. Потім вийти на шляхи відходу ясського угруповання противника на південь, відрізати шляхи відходу кишинівського угруповання німецьких військ на захід та продовжити наступ в межиріччі на південь (Великая Отечественная война. 1941-1945. Военноисторические очерки. 1999: 47; ЦАМО, 240 - 2779 - 1150: 125; Великая Отечественная война 1941-1945 годов: T. 1, 2015: 204).

Використавши паузу в активних бойових діях 312 по 26 квітня німецькі війська також укріпили свої бойові порядки. На північ від міста Ясси було перекинуто $24 m$ та посилено німецьке угруповання $17 m \partial$ та 23 mд. Бойовий склад 4-ї румунської армії було збільшено на сім дивізій. Для забезпечення стійкості своєї оборони на ділянці Тиргу-Няму, Тиргу-Фрумос, Ясси німецьке командування розташувало румунські і німецькі з’єднання упереміж. До кінця квітня межиріччі Прута і Серета в першій смузі оборони знаходились вісім дивізій, а у другому ешелоні - п'ять тд і мд з шести наявних на той час (Великая Отечественная война. 1941-1945. Военно-исторические очерки. 1999: 48).

26 квітня війська правового крила 2 УФ розпочали наступ на допоміжних ясському та кишинівському напрямках, щоб відволікти резерви противника з головного напрямку, однак прорвати сильно укріплену оборону противника на всю глибину війська фронту не змогли. Наступ, що продовжувався у наступні дні, успіху також не мав. Співвідношення сил на напрямку головного удару 2 УФ по піхоті 3:1, артилерії 3:1 і танках 2:1 виявилося 
недостатнім для прориву міцної оборони противника. Тим більш німецькі війська постійно контратакували, намагаючись скинути війська 52 А та 27 А радянських військ за р. Прут. Наступ лівого крила фронту на Кишинів також був невдалим. Після невдалих наступальних дій війська 2 УФ почали здійснювати часткове перегрупування і підготовку до нового наступу з метою прориву оборони противника в районі Тиргу-Фрумос і виходу на комунікації яссько-кишинівського угруповання противника. Найближче бойове завдання для фронту залишилось незмінним - захопити Ясси і Кишинів, розгромити угруповання німецьких військ та просунутися в межиріччя на південь (ЦАМО, 240 - 2779 - 992: 5, 7).

Загалом, протягом квітня німецьке угруповання перед 2 УФ було посилено 17 дивізіями та займало підготовлену оборонну смугу на лінії Пашкани, Ясси, Корнешти, гирло р. Реут, р. Дністер. Співвідношення сил між протиборчими сторонами на цей час скоротилося не на користь радянських військ і складало по піхоті 2:1, артилерії 1,3:1, танках 0,9:1. На напрямку Тиргу-Фрумос, Ясси противник зосередив дві тд та одну мд (23-тя, 24-та, дивізія СС «Велика Німеччина»), які містили у своєму складі 115 танків та самохідних установок (САУ). то СС «Мертва голова» (40 танків) знаходилась на напрямку Пятра. На напрямку головного удару радянських танкових військ - район Тиргу-Фрумос протистояла лише мд СC «Велика Німеччина» (25 танків), яка займала оборону на рубежі Бербетешть, Кукутень (рис. 1) (ЦАМО, 240 - 2779 - 992: 27; ЦАМО, 240 - 2779 - 1155: 208; ЦАМО, 240 - 2779 - 1155: 290).

Для здійснення прориву на Тиргу-Фрумоському напрямку у взаємодії з загальновійськовими з'єднаннями та розвитку успіху вглибину було виділено 2 ТА та 5 гв. ТА, які мали на озброєнні 380 танків та 111 САУ. Враховуючи, що німецькі війська на напрямку головного удару мали лише 25 танків, то співвідношення у бронетанковій техніці складало майже 1:20, що свідчило про значну перевагу радянських військ. Однак, німецьке командування розгадало наміри противника та до початку операції спішно перекинуло 3 напрямку Пятра на південь від ТиргуФрумос тд СС «Мертва голова», а також посилило своє угруповання в цьому районі 4-ю румунською піхотною дивізією (ЦАМО, 240 - 2779 - 1155: 292). 
2 травня війська 2 УФ після годинної артпідготовки перейшли в наступ на Тиргу-Фрумоському напрямку. На початковому етапі 27 А на правому фланзі силами 35 гв. ск у взаємодії із частинами 2 ТА частково прорвала оборону противника на фронті Блажешті, Ходова протяжністю 20 км. по фронту та від 4 до 10 км углиб. Незначний успіх мала і 7 гв. А, яка наступала у взаємодії із частинами 5-ї гвардійської танкової армії та вклинилась в німецьку оборону на глибину до 10 км. Інші з'єднання фронту, які не мали підсилення танковими з'єднаннями для прориву оборонної смуги, в глибину оборони противника не просунулися. Протягом 3 та 4 травня на правому фланзі прориву фронту 5 гв. ТА та 7 гв. А успіху не мали, так як зупинилися перед другою лінією оборони противника, яка складалася 3 дотів, дзотів та мінних полів. На лівому фланзі прориву фронту війська 2 ТА прорвалися на північну околицю Тиргу-Фрумос, але без підтримки загальновійськових з'єднань 27 А вимушені були відійти. Спроба наступу радянських військ з ранку 5 травня успіху не мала. В ході запеклих боїв німецькі війська постійно контратакували та навіть захоплювали важливі командні висоти. У своєму наказі від 7 травня № 00349 Командувач 2 УФ наказував утримувати панівні висоти до останнього патрона, аж до рукопашної сутички (ЦАМО, 240 - 2779 - 1155: 216, 231, 232, 293).

Перед військами 2 УФ оборона противника була побудована потужно і глибоко, з укріпленими районами, насиченими залізобетонними спорудами. Особливо надійно німецьке командування зміцнило межиріччя Прута і Серета. На ясському напрямку воно створило чотири оборонні рубежі на глибину до 80 км. Перший 3 них проходив по висотах на північ від Ясс; другий з основними вузлами опору Тиргу-Фрумос, Поду-Ілоаей, Ясси - по річці Бахлуй; третій пролягав вздовж північних галявин лісових масивів, що покривають вершину гірського хребта Маре. I, нарешті, потужний четвертий рубіж - Фокшанський укріплений район. Було укріплено всі висоти, посилено штучними спорудами круті схили долин і крутосхили берегів річок, відроги хребта Маре і великі лісові масиви. В цих районах налічувалось майже 350 залізобетонних споруд. Щільність артилерійського вогню тут була доведена до 40 та більше гармат на один кілометр фронту (Ясско-Кишиневские Каннь, 1964: 50; Тельпуховский, 1959: 381, 382). 
Тактична зона оборони німецьких військ перед з'єднаннями 2 УФ була побудована у декілька ліній. Так, оборона 6-ї румунської піхотної дивізії на південь від району Содомень (напрямок Пятра) складалася 3 3-х ліній: перша лінія - доти, що з'єднувалися траншеями, по переду цієї лінії було встановлено дротову загорожу та мінні поля; друга - суцільна траншея на віддаленні 200 м від першої лінії, третя лінія знаходилась на відстані близько 500-600 м від другої, являла собою ряд опорних пунктів, обладнаних бліндажами для резервів, що прикривались загорожами 3 дроту. 1-ша румунська гвардійська піхотна дивізія оборонялася на позиціях, що складалася 3 дотів, дзотів і траншей. Доти і дзоти розташовувалися в три ряди у шаховому порядку на відстані 400-500 м один від одного. Попереду дотів проходив протитанковий рів (ЦАМО, 240 - 2779 - 1155: 292; ЦАМО, 1720 0001 - 0153: 359; ЦАМО, 240 - 2779 - 869: 177).

За такої побудови оборони німецького угруповання на ясськокишинівському напрямку радянські війська не змогли 3 ходу подолати супротив противника, що встиг зайняти заздалегідь підготовлену смугу оборони з побудованими дотами та дзотами. Війська 2 УФ, що мали завдати удару на Тиргу-Фрумос та в подальшому на Ясси і Роман, втратили раптовість та свого завдання щодо глибокого прориву оборони противника з виходом у межиріччя Серета та Пруту не виконали.

Що б організувати іiі прорив необхідний був час для здійснення відповідного перегрупування військ та підтягування тилів, що постійно відставали в умовах весняного бездоріжжя. Тому, згідно з рішенням Ставки ВГК з 7 травня 2 УФ перейшов до оборони. Слід зазначити, що при цьому командувач фронтом перегрупування сил не здійснив, підпорядковані армії перейшли до оборони в тих розмежувальних лініях і з тими ж засобами посилення, які вони мали в період наступу. В результаті найбільша щільність військ в обороні виникла на напрямках, де проводились наступальні дії. Тільки наприкінці травня, у зв'язку 3 наступом німецьких військ у районі Ясс, командувач фронтом ввів у першу лінію в смузі 27 А 5 гв. А та здійснив часткове перегрупування артилерії (ЦАМО, $148 a$ - 3763 - 166: 359; ЦАМО, 240 - 2779 - 992: 28, 29). 
Внаслідок відсутності досвіду ведення бойових дій в умовах предгірського і гірського характеру місцевості радянські війська в період з 2 по 6 травня мали значні втрати в особовому складі, у військовій техніці та озброєнні, зокрема у бронетанковому. Тільки у 5 гв. ТА після переходу до оборони залишилось лише 186 танків (38 з яких були передані на підсилення 7 гв. А) 3244 , що були у їі складі на 1 травня, тобто втрати у бронетехніці склали майже 24\% (ЦАМО, 240 - 2779 - 1157: 9; ЦАМО, 240 2779 - 1157: 34).

Протягом травня німецьке командування посилило своє угруповання на яссько-кишинівському напрямку $11 n d$ та $8 n d$ (легкою). Отже, на початку червня 2 УФ протистояло вже 37 дивізій противника, з них піхотних - 25, танкових -7 , мотопіхотна -1 , адд - 1, кінна - 1 (рис. 2) (ЦАМО, 240 - 2779 - 992: 27).

Командуванням Вермахту, 3 метою ліквідації вигідного плацдарму для наступу 52 А радянських військ на південь від Ясс було сплановано проведення часткових наступальних операцій, які надалі отримали назви «Соня» i «Катя». Для цього у зазначеному районі було зосереджено: у першому ешелоні 3 nd, $11 n \partial$ (румунські), 23 mд та $79 n \partial$ (німецькі); у другому ешелоні - 24 mд та 14 mд (німецькі). Авіаційне угруповання включало майже 1000 літаків люфтваффе та румунських військово-повітряних сил. Деякі російські джерела зазначають, що наприкінці травня - початку червня в боях під Яссами німецьке командування задіяло 10 своїх дивізій (ЦАМО, 240 2779 - 992: 27; ЦАМО, 240 - 2779 - 869: 178; Малютина, 2018: 62; Малютина, 2019: 404; Бодрихин, 2010: 88; Великая Отечественная война. 1941-1945. Военно-исторические очерки, 1999: 82).

Планом операції «Соня» $(30-31$ травня) передбачалося силами 14 mд і 23 mд здійснити прорив оборони радянських військ у напрямку Редіу-Алдей - Стинка, у стик 73-го та 48-го стрілецьких корпусів $(c \kappa)$. Від Стинки німецькі танкові дивізії мали продовжити наступ уздовж висот на південь від р. Жижія до району на схід від Редіу-Мітрополії. 24 mд від Стинки мала нанести удар на південний захід (вис. 162) (Малютина, 2018: 63; ЦАМО, 240 - 2779 - 869: 177). 
Зранку 30 травня після артпідготовки та масованого удару авіації (до 1800 бойових вильотів протягом дня) німецькі війська перейшли в наступ у напрямку на Кирпицій та півничний захід на Ларга вздовж ділянки лівого флангу 73 ск і правового флангу $48 c \kappa 52 \mathrm{~A}$ та за 3 дні важків боїв вклинилися в оборону радянських військ на фронті до 9 км та на глибину до 4 км. У ході наступу танкові і мотомеханізовані частини німецького угруповання, які діяли у другому ешелоні, проходячи через бойові порядки свого 1-го ешелону, підіймали за собою в наступ румунські частини, нарощуючи при цьому силу удару (ЦАМО, 240 - 2779 - 869: 178).

Незважаючи на те, що напередодні наступу, ще 29 травня, радянська авіація силами 5 ПА несподівано завдала удару по аеродромах противника Роман і Хуші, в результаті чого було виведено з ладу майже 70 літаків (знищено 35 та пошкоджено 25), повітряна обстановка все ж такі в перші два дні наступу була на користь люфтваффе та румунських військово-повітряних сил. Це було обумовлено як чисельною їх перевагою у повітрі (безперервно діяло до 700 літаків), так і застосуванням прогресивної тактики повітряного нападу, що полягала у здійсненні наступу одночасно двома повітряними ешелонами (верхнім та нижнім). Це дозволило вирішити одночасно два завдання: бомбардування наземних радянських військ та блокування дії їх штурмовиків. У відповідь командування 5 ПА змінило тактику взаємодії винищувачів зі штурмовиками та бомбардувальниками. Склад групи винищувачів збільшувався у два-три рази, при цьому частка літаків мала вести бій у повітрі, а решта - заздалегідь здійснювати пошук і знищення ворожих винищувачів, не допускаючи їх до своєї повітряної ударної групи. Повітряний напад здійснювався ешелонами послідовно (Клевцов, 1989: 83, 84).

За даними румунського командування, тільки за два дні (30 31 травня) радянськими військами було втрачено 60 танків та 70 літаків. Не зважаючи на раптовість та потужність удару німецького угруповання, мета операції «Соня», щодо зайняття панівних висот у районі Ясс досягнута не була. Для розвитку та закріплення часткового успіху в цій операції німецьким командуванням було прийнято рішення щодо проведення нової операції 
під назвою «Катя» (2-6 червня) (ЦАМО, 240 - 2779 - 992: 27 29; Малютина, 2019: 405, 406).

31 червня у підпорядкування румунської 4 А переходила німецька 24 mд. Ударна група армії отримала завдання щодо знищення противника на «фланзі на захід від предмістного укріплення Ясси». Напрямок атаки - на схід від залізниці в районі Лецкань, потім на північ з метою захопити перехрестя залізниці і автодороги в 5км на південний захід від Єпурень. Після виконання цього завдання планувалось вийти до РедіуМітрополії і встановити зв'язок з групою Мієт, яка мала атакувати в напрямку Утес і ліс, на південний захід від Захорна (Малютина, 2018: 64).

Для розширення фронту наступу, не припиняючи наступальні дії на північ від Ясс, 2 червня німецькі війська силами, мд «Велика Німеччина» та румунських 18-ї гірсько-стрілецької дивізії та $5 n d$ завдали удару з рубежу залізниця, Таутошти в загальному напрямку на Єпурень, зав'язалися запеклі бої. За даними румунських джерел мд «Велика Німеччина» цього дня втратила близько 50 танків, з яких 9 було повністю знищено, а решта - ушкоджено. Водночас, також зазнавши значних втрат та під тиском противника, радянські війська почали залишати позиції, що займали і вигідні висоти. В наступні дні, потіснивши частини $116 c d$ та $73 c \kappa 52 \mathrm{~A}$, німецькі війська захопили три висоти $(162,152$ та 154), а 5 червня за підтримки румунських $11 n \partial$ та $3 n d, 79 n \partial$ німецької, $14 m \partial, 23 m \partial$ та часткою сил $24 m \partial$ намагались постійними атаками вибити частини i з'єднання 52 А $з$ висот у р. Жижія. Про запеклість боїв за висоти на північ від Ясс свідчив колишній німецький пілот-ас ГансУльрих Рудель, який згадував про неодноразове опанування руїн замку на так званій Замковій горі по черзі німецькими або радянськими військами (ЦАМО, 240 - 2779 - 992: 28, 29; Малютина, 2018: 64; Рудель, 2003: 156). В цих боях відзначився своєю мужністю і героїзмом українець рядовий Роман Смищук, який в першому своєму зіткненні з ворогом, будучи в оточенні, гранатами та пляшками 3 запальною сумішшю знищив 6 середніх танків противника. За цей подвиг наш земляк був удостоєний звання Героя (ЦАМО, 53 - 686043 - 62: 10). 
Послабленій у боях 52 А 2 УФ необхідне було підсилення за рахунок резервів фронту. Як зазначав колишній командувач фронтом маршал Маліновський Р.Я., «удари противника були досить відчутними. $52 \mathrm{~A}$, що займала фронт перед Яссами надсилала неприємні донесення про втрату траншей, позицій та висот. Виникла загроза, що ми лишимося висот у районі Ясси і опинимося в дуже небезпечному оперативному (тактичному) становищі». Однак Ставка ВГК відмовилась від введення в бій резерву, мотивуючі втягуванням сил фронту в затяжні бої (Освобождение Юго-Восточной и Центральной Европь войсками 2-го и 3-го Украинских фронтов, 1970: 49; Малиновский, 1959: 26). В цих умовах командувачем 2 УФ 4 червня було видано наказ № 00395/оп щодо відновлення служби загороджувальних загонів для припинення випадків виходу з полю бою як окремих воїнів, так і груп військовослужбовців (ЦАМО, 240 - 2779 - 1160: 31).

Однак, 6 червня наступ німецьких військ на ясському напрямку було призупинено. В результаті семиденних напружених боїв вони покращили своє тактичне становище на північ та північний захід від Ясс, захопили низку важливих висот та вклинилися в оборону ЧА по фронту до 19 км. Внаслідок цього, правофлангові частини 52 А 2 УФ, вимушені були закріпитися на невигідних рубежах, біля болотистих заплав річок Жижія і Прут, що позбавило іiі можливості побудови глибокої оборони (ЦАМО, 240 - 2779 - 992: 28, 29).

Протиборчі сторони в ході запеклих боїв зазнали значних втрат. Так, у звіті про бойові дії 52 А за червень 1944 року зазначено про втрати іiі особового складу за період з 30 травня по 6 червня 1944 року, які склали вбитими - 2297 осіб, пораненими - 10615 осіб. За цей період втрати німецьких військ склали: вбитими та пораненими - 13500 осіб, бронетехніка 136 одиниць, артилерійських гармат - 49, літаків - 44 (ЦАМО, 408 - 9991 - 311: 26). При цьому, 5 ПА за цей час бойових дій втратила 221 літак, а не бойові втрати склали, крім того, 53 літаки. Водночас фундаментальне видання «Історія Другої світової війни. 1939-1945» зазначає, що протягом семи діб бойових дій німецькими військами було втрачено понад 27000 осіб, 500 танків та 366 літаків (История Второй мировой 
войны 1939-1945 г2., 1977: 100; Бодрихин, 2010: 88). У цих боях відзначився видатний льотчик Другої світової війни українець Іван Кожедуб, який тільки 331 травня по 8 червня знищив 8 ворожих літаків (Воздушные победы Ивана Кожедуба, 2008).

Для наступальних дій з боку протиборчих сторін під час проведення операцій «Соня» та «Катя» характерним стало застосування крупних сил бронетанкових і механізованих військ. За свідченнями командувача румунської 4 А генерала Раковіце ці операції надали урок танкового наступального бою в умовах сильної та організованої оборони. За його словами, танки, за підтримки авіації та артилерії, стали потужним засобом прориву (Малютина, 2019: 410).

На початку червня німецькі та радянські війська на ясськокишинівському напрямку перейшли до жорсткої оборони. Такий стан справ влаштовував обидві протиборчі сторони. Так, у зв'язку з підготовкою наступу військ РСЧА в Білорусії командувач 2 УФ мав передати в резерв Ставки ВГК дві танкові, одну загальновійськову армії та декілька дивізій. По-друге, необхідно будо дезорієнтувати противника відносно істинного угруповання своїх військ, їх стану та намірів. Для цього необхідно було постійно підкреслювати відсутність намірів радянського командування продовжувати наступ на яссько-кишинівському напрямку (Великая Отечественная война. 1941-1945. Военно-исторические очерки, 1999: 82).

Німецьке командування в свою чергу вважало, що в ході проведення бойових дій 330 травня по 6 червня радянські війська значно ослабли, а відновлення їх наступальних дій на півдні навряд чи можливе. Тому, воно здійснило перегрупування частки своїх військ з метою виводу їх у резерв на поповнення та відправки на інші фронти. Це дозволило відвести у другий ешелон та зосередити в районі Тиргу-Фрумос - Ясси то $C C$ «Мертва голова», 24 mд, 23 mд, 14 mд, а також відправити 3 цього напрямку на захід для підсилення групи армій «Центр» мд «Велика Німеччина», 11 тд та 34 пд (Никитенко. 1994: 3; ЦАМО, 240 - 2779 - 992: 44). В подальшому, із групи армій «Південна Україна» на центральну ділянку фронту було перекинуло 12 німецьких дивізій, у тому числі 6 танкових та 1 моторизовану. 
У результаті обстановка, що склалася перед Яссько-Кишинівською операцією, виявилася сприятливою для радянського командування у підготовці своїх військ до наступу (Великая Отечественная война. 1941-1945. Военно-исторические очерки, 1999: 82; История Великой Отечественной войны Советского Союза 19411945 г2., 1962: 266).

Отже, бойові дії між 2 УФ та Вермахтом у квітні-червні 1944 року на яссько-кишинівському напрямку, на думку авторів, проходили у три етапи.

На першому етапі, що тривав 35 квітня по 2 травня, в результаті раптового удару війська правового крила фронту захопили важливі населені пункти Ботошани, Дорохой та навіть ТиргуФрумос. Однак внаслідок контратак з боку противника та без підтримки танкових з'єднань, що затримались на марші у зв'язку з весняним бездоріжжям, вони потрапили в оточення під Тиргу-Фрумосом та вимушені були зупинитись. Одночасно війська лівого крила фронту опанували Дубоссари, Грігоріопіль та вийшли на р. Дністер. На цей момент між радянськими i німецькими військами склалося співвідношення, за яким подальший наступ військ 2 УФ був недоцільним. Тому командувач фронту 12 квітня прийняв рішення про перегрупування своїх військ та завдання головного удару західніше від Ясс. Наступ радянських військ на Ясси та Кишинів, що розпочався 26 квітня, не дозволив прорвати сильно укріплену оборону противника на всю їі глибину. Командування ЧА прийняло рішення про подальше часткове перегрупування своїх сил і підготовку до нового наступу з метою прориву оборони противника в районі Тиргу-Фрумос.

На другому етапі, 22 по 30 травня, радянські війська здійснили наступ на тиргу-фрумоському напрямку, частково прорвали німецьку оборону та вклинились у глибину на відстань до 10 км. Однак, з ходу подолати супротив противника, що встиг зайняти заздалегідь підготовлену смугу оборони з побудованими дотами та дзотами, не змогли. 37 травня 2 УФ перейшов до оборони. До кінця травня командувачем фронту було здійснено часткове перегрупування 3'єднань та артилерії. Німецьке командування тим часом посилило своє угруповання на яссько-кишинівському напрямку двома піхотними дивізіями та готувалось до наступу. 
Основні його зусилля були сконцентровані на ясському плацдармі, де було зосереджено 10 дивізій, в тому числі 3 танкових.

На третьому етапі, з 30 травня по 6 червня, німецьким командуванням 3 метою ліквідації вигідного плацдарму для наступу 52 А ЧА на південь від Ясс було проведено дві наступальні операції. В результаті семиденних бойових дій радянські війська втратили декілька панівних висот, а правофлангові частини $52 \mathrm{~A}$ вимушені були закріпитися на невигідних рубежах. Однак своєї кінцевої мети німецьке командування не досягло, війська ЧА міцно утримували Ясський плацдарм.

Таким чином, завдання Ставки ВГК щодо оволодіння містами Кишинів та Ясси у квітні-червні 1944 року війська 2 УФ не виконали. Німецькому командуванню вдалося організувати міцну оборону на заздалегідь підготовлених оборонних спорудах та вміло використати особливості гористої місцевості Карпат, де радянські війська не мали бойового досвіду. Далася взнаки і поспішність введення в бій командуванням ЧА з'єднань в умовах весняного бездоріжжя. Водночас, контрнаступ німецьких військ наприкінці травня та початку червня привів лише до часткового захоплення панівних висот навколо Ясс. Зазнавши значних втрат в особовому складі та військовій техніці під час ведення бойових дій на яссько-кишинівському напрямку обидві протиборчі сторони 37 червня перейшли до оборони та активних бойових дій до серпня не проводили. Цьому також сприяла необхідність передачі їх з'єднань 3 цього напрямку для посилення своїх угруповань в Білорусії, де готувався наступ радянських військ.

Бойові дії на яссько-кишинівському напрямку у квітні-червні 1944 року виділялись масовим застосуванням з обох протиборчих сторін бронетанкових і механізованих військ, які у взаємодії з авіацією та артилерією були потужним засобом прориву сильно укріпленої оборони в умовах гористої місцевості. У повітрі німецька та радянська авіація в залежності від умов обстановки застосовували різні тактичні прийоми і способи. Люфтваффе зазвичай здійснювало повітряний наступ у двоешелонному порядку один над другим. Радянське повітряне командування, напроти, притримувалось тактики послідовних ешелонів, значно посилених винищувальною авіацією. 


\section{Використані посилання}

Бодрихин Н. (2010). Кожедуб. Москва, Молодая гвардия, 431 с.

Важнейшие операции Великой Отечественной войны 1941-1945 г2.: сборник статей. (1956). Москва, Воениздат, 623 с.

Великая Отечественная война 1941-1945 годов: в 12 m. T.1: Основные события войны (2015). Москва, Кучково поле. 976 с.

Великая Отечественная война 1941-1945 годов: в 12 т. Т.4: Освобождение территории СССР. 1944 год (2015). Москва, Кучково поле. 864 с.

Великая Отечественная война. 1941-1945. Военно-исторические очерки. Книга третья. Освобождение. (1999). Москва, Наука, 510 с.

Великая Отечественная война Советского Союза 1941-1945: Краткая история. 3-е изд., испр. и доп. (1984). Москва, Воениздат, 560 с.

Воздушные победы Ивана Кожедуба. URL: http://www.airaces.ru/asy-velikojjotechestvennojj-vojjny/kozhedub-ivan-nikitovich.html [дата звернення: 06.05.2021].

Генералы и офицеры вермахта рассказывают... Документы из следственных дел немецких военнопленных 1944-1951. Вступ. ст., сост. В. Г. Макарова, В. С. Христофорова; коммент. В. Г. Макарова. (2009). Москва, МФД, 576 с.

Грицюк В.М. (2012). Яссько-Кишинівська операція (2-6.05.1944р.): Забуті сторінки війни. Досвід застосування збройних сил у світових війнах $і$ воєнних конфліктах XX - початку XXI ст.: збірник наукових праць. Вип. 5. С. 121-124.

Золотарев В. А. (2010). История Великой войны 1941-1945: в 2 томах. Москва, ИНЭС, РУБИН. Т. 2. 592 с.

История Великой Отечественной войны Советского Союза 1941-1945 г2.: в 6 т. Т. 4: Изгнание врага из пределов Советского Союза и начало освобождения народов Европь от фашистского ига (1944 год) (1962). Москва, 1960-1965. $740 \mathrm{c}$.

История Второй мировой войны 1939-1945 г2.: в 12 т. Т. 8: Крушение оборонительной стратегии фашистского блока. (1977). Москва, Воениздат, 1973-1982. $536 \mathrm{c.}$

Клевцов И.В. (1989). Записки «трижды воскресшего». Ижевск, Удмуртия, $160 \mathrm{c}$.

Малиновский Р. (1959). Из воспоминаний о Ясско-Кишиневской операции (август - сентябрь 1944 года). Военно-исторический журнал. № 2. С. 25-34.

Малютина Т.П. (2018.) На безымянных высотах под Яссами. 4-я румынская армия в операциях “Соня” и “Катя” (май-июнь 1944 года). Вестник ВГУ. Серия: История. Политология. Сочиология. № 4. С. 62-66.

Малютина Т.П. (2019). История боевых действий советских войск против вооруженных сил Королевской Румынии на советско-германском фронте (1941-1944 г2.). Москва, 523 с.

Минц И.И. (1947). Великая Отечественная война Советского Союза. Москва, Госполитиздат, $71 \mathrm{c.}$

Назария С.М., Поливцев В.Н. (2015). «Ясско-Кишинёвские Канны»- самая блестящая наступательная операция Второй мировой войны и её интерпретации в современной румынской историографии. Русин. № 2 (40). С. 227-240. 
Никитенко Е.Г. (1994). Освобождение Молдавии. Военно-исторический журнал. № 7. С. 2-13.

Освобождение Юго-Восточной и Центральной Европь войсками 2-го и 3-го Украинских фронтов. (1944-1945) (1970). Москва, Наука, 676 с.

Рудель Г. (2003). Пилот «Штуки». Москва, Центрполиграф, 272 с.

Грицюк В., Лисенко О., Пилявець Р., Сидоров С. Стратегічні та фронтові операиії на території України у 1943-1944 роках (2015) Київ, Національний університет оборони України імені Івана Черяховського, Інститут історії України НАН України, 508 с.

Тельпуховский Б.С. (1959) Великая Отечественная война Советского Союза 1941-1945 г2.: краткий очерк. Москва, Политиздат, 575 с.

Типпельскирх Курт фон (1998). История Второй мировой войны 1939-1945. Санкт-Петербург, Полигон, 796 с.

Центральный архив Министерства обороны Российской Федерации (далі ЦАМО). Ф. 53. Оп. 686043. Д. 62. Указ Верховного Совета СССР от 12.06.1944 о присвоении звания Героя Советского Союза красноармейиу Смишук Роману Семеновичу.

ЦАМО. Ф. 148а. Оп. 3763. Д. 166. Директива Ставки ВГК от 22 марта 19442. № 220054 Командуюшему войсками 2-го Украинского фронта на окружение группировки противника в районе нижнего течения Южного Буга.

ЦАМО. Ф. 148а. Оп. 3763. Д. 166. Директива Ставки ВГК от 5 апреля 1944 2. № 220072 Командующему войсками 2-го Украинского фронта об ускорении выхода на рр. Сирет и Бахлуй.

ЦАМО. Ф. 148а. Оп. 3763. Д. 166. Директива Ставки ВГК от 6 апреля 1944 2. № 220073 Командуюшему войсками 2-го Украинского фронта об ускорении выхода на рр. Сирет и Бахлуй.

ЦАМО. Ф. 148а. Оп. 3763. Д. 166. Директива Ставки ВГК от 6 мая 1944 г. № 220094 Командующему войсками 2-го Украинского фронта на переход к обороне.

ЦАМО. Ф. 240. ОП. 2779. Д. 869. Краткая сводка № 5 обобщенного боевого опыта войск 52 А за июнь 1944 г.

ЦАМО. Ф. 240. Оп. 2779. Д. 992. Отчеты о боевой деятельности 2 УкрФ за апрель и май месяияы 1944 г.

ЦАМО. Ф. 240. Оп. 2779. Д. 992. Доклад об итогах боевой деятельности войск 2 УкрФ за июнь месяи 1944 г.

ЦАМО. Ф. 240. Оп. 2779, Д. 1140. План Уманской операции 2-го Украинского фронта.

ЦАМО. Ф. 240. Оп. 2779. Д. 1146. Выписка из журнала боевых действий 2 УкрФ за март месяи 1944 г.

ЦАМО. Ф. 240. Оп. 2779. Д. 1150. Выписка из журнала боевых действий 2 УкрФ за апрель месяи 1944 г.

ЦАМО. Ф. 240. Оп. 2779. Д. 1150. Доклад Командующего войсками 2-го Украинского фронта Верховному Главнокомандующему.

ЦАМО. Ф. 240. Оп. 2779. Д. 1155. Выписка из журнала боевых действий 2 УкрФ за май месяи 1944 г. 
ЦАМО. Ф. 240. Оп. 2779. Д. 1157. Доклад о боевых действиях бронетанковых и механизированных войск 2 УкрФ в Тыргу-Фрумосской операции (2.5.-8.5.44 2.).

ЦАМО. Ф. 240. ОП. 2779. Д. 1157. Ведомость боевого и численного состава войск 2 УкрФ на 01.05.1944.

ЦАМО. Ф. 240. Оп. 2779. Д. 1160. Журнал боевых действий 2 УкрФ за июнь месяи 1944 г.

ЦАМО. Ф. 240. Оп. 2779, Д. 1274. Описание Уманской операции.

ЦАМО. Ф. 408. Оп. 9991. Д. 311. Журнал боевых действий 52 А за июнь месяи 1944 года.

ЦАМО. Ф. 1720. Оп. 0001. Д. 0153. Протокол допроса военнопленного румынского капрала 3 б-на 25 пп 15 пд 3 ак.

Ясско-Кишиневские Канны (1964) Москва, Наука. 280 с.

Glantz David M. (2007). Red Storm Over the Balkans: The Failed Soviet Invasion of Romania. Lawrence, University Press of Kansas. $424 \mathrm{c}$.

\section{References}

Bodrikhin N. (2010). Kozhedub. Moscow, Young Guard. 431 p.

Central archive of the Ministry of Defense of the Russian Federation (CAMD). File 53. Description 686043. File no. 62. Decree of the Supreme Soviet of the USSR dated 06,12.1944 on awarding the title of Hero of the Soviet Union to the Red Army soldier Smishchuk Roman Semenovich.

CAMD. File 148a. Description 3763. File no. 166 Directive of the Supreme Command Headquarters of March 22, 1944, No. 220054 to the Commander of the 2nd Ukrainian Front to encircle the enemy group in the area of the lower reaches of the Southern Bug.

CAMD. File 148a. Description 3763. File no. 166 Directive of the Supreme Command Headquarters of April 5, 1944, No. 220072 to the Commander of the 2nd Ukrainian Front on accelerating the exit to the Siret and Bahlui rivers.

CAMD. File 148a. Description 3763. File no. 166. Directive of the Supreme Command Headquarters dated April 6, 1944 No. 220073 to the Commander of the 2nd Ukrainian Front on accelerating the exit to the river. Siret and Bahlui.

CAMD. File 148a. Description 3763. File no. 166. Directive of the Supreme Command Headquarters of May 6, 1944, No. 220094 to the Commander of the 2nd Ukrainian Front on the transition to defense.

CAMD. File 240. Description 2779. File no. 869 Brief summary No. 5 of the generalized combat experience of troops 52 A for June 1944.

CAMD. File 240. Description 2779. File no. 992 Reports on the combat activities of the 2nd Ukrainian Front for April and May 1944.

CAMD. File 240. Description. 2779. File no. 992 Report on the results of the combat activities of the troops of the 2nd Ukrainian Front for June 1944.

CAMD. File 240. Description 2779. File no. 1140 Plan of the Uman operation of the 2nd Ukrainian Front.

CAMD. File 240. Description 2779. D. 1146 Extract from the combat operations log of the 2nd Ukrainian Front for the month of March 1944. 
CAMD. File 240. Description 2779. D. 1150 Extract from the combat operations log of the 2nd Ukrainian Front for the month of April 1944.

Generals and officers of the Wehrmacht tell ... Documents from the investigation files of German prisoners of war. 1944-1951. Entry. Art., comp. V. G. Makarova, V. S. Khristoforova; comment. V. G. Makarova. (2009). Moscow, MFD. 576 p.

Gritsyuk V. (2012). Iași-Chișinău operation (May 2-6, 1944): Forgotten pages of the war. Experience in the use of armed forces in world wars and military conflicts of the XX - early XXI centuries: collection of scientific works. Iss. 5. P. 121-124.

History of the Great Patriotic War of the Soviet Union 1941-1945: in 6 volumes. Vol. 4: Expulsion of the enemy from the borders of the Soviet Union and the beginning of the liberation of the peoples of Europe from the fascist yoke (1944) (1962). Moscow, $740 \mathrm{p}$.

History of World War II 1939-1945: in 12 volumes Vol. 8: The collapse of the defensive strategy of the fascist bloc. (1977) Moscow, Military Publishing, 536 p.

Ivan Kozhedub's aerial victories (16th breast, 2008). URL: http://www.airaces.ru/ asy-velikojj-otechestvennoij-vojjny/kozhedub-ivan-nikitovich.html [Accessed: 05.06.2021].

Klevtsov I. (1989). Notes of "Thrice Resurrected”. Izhevsk, Udmurtia. 160 p.

Liberation of South-Eastern and Central Europe by the troops of the 2nd and 3rd Ukrainian fronts. (1944-1945) / under total. ed. M. Zakharova. (1970). Moscow, Science. $676 \mathrm{p}$.

Malinovsky R. (1959). From the memoirs of the Jassy-Kishinev operation (August September 1944). Military history journal. No. 2. P. 25-34.

Malyutina T. (2018). On unnamed heights near Yassy. 4th Romanian Army in the operations "Sonya" and "Katya" (May - June 1944). VGU Bulletin. Series: History. Political science. Sociology. No. 4. P. 62-66.

Malyutina T. (2019). History of military operations of Soviet troops against the armed forces of Royal Romania on the Soviet-German front (1941-1944). Moscow, 523 p.

Mints I. (1947). The Great Patriotic War of the Soviet Union. Moscow, Gospolitizdat. $71 \mathrm{p}$.

Nazariya S., Polivtsev V. (2015). Iași-Chișinău Cannes” is the most brilliant offensive operation of the Second World War and its interpretation in modern Romanian historiography. Rusin. No. 2 (40). P. 227-240.

Nikitenko E.G. (1994). Liberation of Moldova. Military history journal. No. 7. P. 2-13.

Rudel G. (2003). Stuka-Pilot. Moscow, Tsentrpoligraf, 272 p.

Hrytsiuk V., Lysenko O., Pylyavets R., Sidorov S. Strategic and front operations on the territory of Ukraine in 1943-1944 (2015). Kyiv, The National Defence University of Ukraine named after Ivan Cherniakhovskyi, Institute of History of Ukraine National Academy of Sciences of Ukraine. 508 p.

Telpukhovsky B. (1959) The Great Patriotic War of the Soviet Union 19411945: a brief outline. Moscow, Politizdat. 575 p.

The Great Patriotic War of 1941-1945: in 12 volumes. Vol. 1: The main events of the war. (2015). Moscow, Kuchkovo field. 976 p.

The Great Patriotic War of 1941-1945: in 12 volumes. Vol. 4: Liberation of the territory of the USSR. 1944. (2015). Moscow, Kuchkovo field. 864 p. 
The Great Patriotic War. 1941-1945. Military-historical essays. Book 3. Liberation (1999) Moscow, Nauka, 510 p.

The Great Patriotic War of the Soviet Union 1941-1945: A Brief History. 3rd ed. (1984) Moscow, Military Publishing, $560 \mathrm{p}$.

The most important operations of the Great Patriotic War of 1941-1945: Collection of articles (1956). Moscow, Military Publishing. 623 p.

Tippelskirch Kurt von (1998) History of the Second World War 1939-1945. Saint Petersburg, Polygon. 796 p.

Zolotarev V. (2010). History of the Great War 1941-1945: in 2 volumes. Moscow, INES, RUBIN. Vol. 2. 592 p.

\section{Yevseyev I., Hrytsiuk V., Kydon' V., Kryvyziuk L.}

OPERATIONS OF THE RED ARMY AND THE WEHRMACHT IN THE IAȘI-CHIȘINĂU DIRECTION (5 ${ }^{\text {th }}$ April $-6^{\text {th }}$ June, 1944): FORGOTTEN PAGES OF THE SECOND WORLD WAR

Scientific reproduction and analysis of the events that took place many years ago allow us to understand the essence of historical phenomena, processes and patterns, to identify distinctive and special, as well as new and original things that have appeared in the art of war. Comprehensive, objective and unbiased study of militaryhistorical events in Ukraine during the Second World War is important from the point of view of establishing historical truth.

The authors of the the article, on the basis of scientific publications and archival documents about studying and using the experience of war, research little-known operations carried out by the warring parties in the Iași-Chișinău direction in AprilJune 1944.

The first Iași-Chișinău operation began after the end of the Uman-Botoshan and Odessa operations in the context of the general strategic offensive of Soviet troops on the Right Bank of Ukraine. In accordance with the plan of the Headquarters of the Supreme High Command, the two Soviet fronts, almost without a pause after a preliminary offensive and appropriate training in April 1944, began active attempts to break into the territory of Romania and Moldova and further into the Balkans.

The first Yasi-Chisinau operation is one of the military operations conducted on the Eastern Front and completely ignored by Soviet historians and experts. The famous military historian David Glanz has written about it. For 76 years after the end of World War II Soviet and Russian historians and theorists have completely eliminated from historical evidence any recollections and references to the role of the 2nd and 3rd Ukrainian fronts in the first battle of Iași and Chişinău, when Soviet troops tried to advance into Romania on two fronts in April-May 1944. As many other failed Red Army military operations, considered by the authors of the article, it was conducted deliberately, eliminating that offensive and sending it to a long list of "forgotten battles" of the German-Soviet war.

Keywords: World War II, 2nd Ukrainian Front, Soviet troops, German troops, Iași-Chişinău direction. 